\title{
Annual and perennial life history strategies of Zostera marina populations under different light regimes
}

\author{
Seung Hyeon Kim ${ }^{1}$, Jong-Hyeob Kim ${ }^{1}$, Sang Rul Park ${ }^{2}$, Kun-Seop Lee ${ }^{1, *}$ \\ ${ }^{1}$ Department of Biological Sciences, Pusan National University, Pusan 609-735, South Korea \\ ${ }^{2}$ School of Marine Biomedical Sciences, Jeju National University, Jeju 690-756, South Korea
}

ABSTRACT: The seagrass Zostera marina is genetically considered to be perennial, but annual populations of this species exist as well and are under severe environmental stress in many geographical locations. We investigated why Z. marina in Jindong Bay (Korea) exhibited a typical perennial life history at a shallow site but an annual life history at a deep site. We hypothesized that $Z$. marina shoots in the deep population die off after fall due to severe light reductions, and that the re-establishment of this population is completely dependent on sexual reproduction. Life histories of these populations were examined by constructing life tables using monthly measurements of shoot recruitment and mortality. In the deep population, new shoot recruitment was only achieved by seedlings, and approximately $95 \%$ of the surviving seedlings flowered. No shoots overwintered in the deep population. In contrast, shoot recruitment in the shallow population was primarily achieved by asexual reproduction. High summer water temperatures and subsequent severe underwater light reduction during summer and fall probably led to the high mortality in $Z$. marina shoots in the deep population, resulting in no shoot survival after fall. The deep population likely exhibits an annual life history strategy to achieve population persistence under repetitive and acute unfavorable environmental conditions. From an evolutionary perspective, the life history traits of $Z$. marina would define this species as an intermediate between annual and perennial.

KEY WORDS: Annuals $\cdot$ Flowering frequency $\cdot$ Life history $\cdot$ Light reduction $\cdot$ Perennials $\cdot$ Reproductive strategy $\cdot$ Seagrass

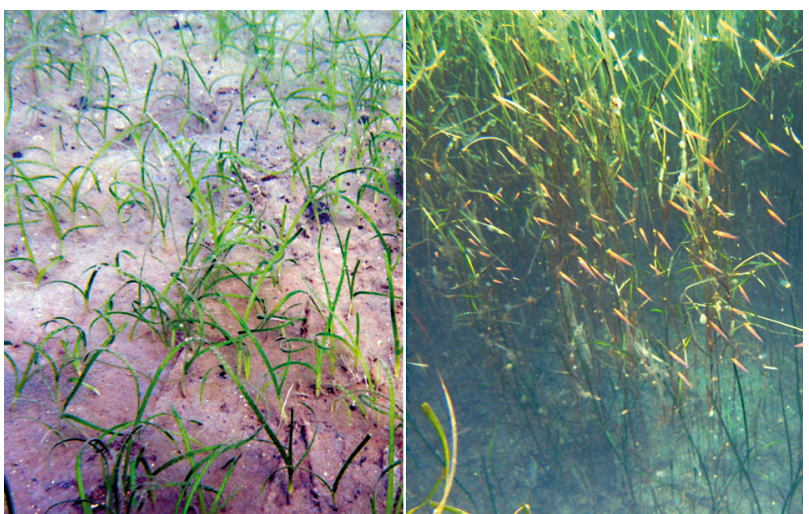

An eelgrass population near its maximum depth limit was reestablished by seedling recruitment (left), and nearly all the surviving seedlings flowered (right).

Image: Seung Hyeon Kim

\section{INTRODUCTION}

Although the annual or perennial life history of flowering plants is generally considered to be genetically fixed (Muñiz-Salazar et al. 2005, van Kleunen 2007), both annual and perennial types of populations have been observed in the seagrass Zostera marina (Moore \& Short 2006). Z. marina is the most widely distributed marine angiosperm in the northern hemisphere and commonly exhibits a perennial life cycle (Cabello-Pasini et al. 2003, Park et al. 2009). Perennial Z. marina populations depend on both asexual and sexual reproduction to maintain existing meadows and colonize new regions, but the contribution of each reproductive strategy varies greatly, 
both spatially and temporally (Olesen 1999, Lee et al. 2005, Jarvis et al. 2012). Annual Z. marina populations, where all vegetative shoots develop to reproductive shoots, have also been observed in several locations (Keddy \& Patriquin 1978, van Lent \& Verschuure 1994, Meling-López \& Ibarra-Obando 1999, Santamaría-Gallegos et al. 2000). Z. marina populations exhibiting an annual life history complete their life cycle within a few months and survive as seeds during unfavorable periods before growing the next generation of plants.

Perennial Z. marina populations are often characterized by low sexual reproductive effort (e.g. <10\% frequency of reproductive shoots; Olesen 1999) and persist mainly via asexual reproduction (new lateral shoot production by rhizome branching; Olesen \& Sand-Jensen 1994, Olesen 1999, Kim et al. 2008). However, rates of more than $50 \%$ flowering frequency have also been reported for perennial Z. marina populations (van Lent \& Verschuure 1994, Meling-López \& Ibarra-Obando 1999, Olesen 1999, SantamaríaGallegos et al. 2000). Variability in flowering frequency among seagrass populations may be associated with environmental heterogeneity (Cabaço \& Santos 2012). High flowering frequencies in seagrass populations occur in areas subject to environmental disturbances such as high water temperature, ice formation, heavy grazing, and sediment disruption by winter storms (Keddy \& Patriquin 1978, van Lent \& Verschuure 1994, Meling-López \& Ibarra-Obando 1999, Santamaría-Gallegos et al. 2000), suggesting that sexual reproduction is advantageous to the maintenance of plant populations under environmental stresses (Plus et al. 2003, Greve et al. 2005, Lee et al. 2007a). Under severe environmental conditions, most eelgrass shoots, and die-off areas are subsequently re-established primarily by seedling recruitment via germination from the seed bank (Robertson \& Mann 1984, van Lent \& Verschuure 1994, MelingLópez \& Ibarra-Obando 1999, Santamaría-Gallegos et al. 2000, Lee et al. 2007a, Jarvis et al. 2012).

Underwater photon flux density (PFD) has been recognized as a major factor controlling the survival and distribution of seagrasses (Dennison \& Alberte 1985, Dennison 1987, Alcoverro et al. 1999, Nielsen et al. 2002). Because compensation irradiance represents the minimum light requirement for plant survival, the duration of PFDs above light compensation points $\left(H_{\text {comp }}\right)$ is closely related to the survival of seagrasses (Dennison 1987). The duration of PFDs above light saturation points $\left(H_{\text {sat }}\right)$ has also been used to predict carbon balance and seagrass production (Dennison \& Alberte 1982, 1985, Zimmerman et al.
$1994,2001)$. Therefore, reduction in underwater light intensity and/or duration is one of the main environmental stresses leading to seagrass declines and affecting distribution patterns (Cabello-Pasini et al. 2002, Holmer \& Laursen 2002, Thom et al. 2008, Biber et al. 2009).

Along the Korean coast, Z. marina grows in the intertidal and subtidal zones, where the water depth is usually $<5 \mathrm{~m}$ (Lee \& Lee 2003). On the southern coast of Korea, Z. marina occurs from $1 \mathrm{~m}$ to $\sim 7 \mathrm{~m}$ depth relative to mean lower low water (MLLW). In the deep area of our study site in Jindong Bay (Korea), all eelgrass shoots - including belowground tissues - die off at the end of the growing season, whereas the eelgrass population at the relatively shallow depth of 1 to $3 \mathrm{~m}$ relative to MLLW persists throughout the year (Kim et al. 2008). The deep $Z$. marina population is likely located near the maximum depth limit of this species and is therefore vulnerable to reductions in underwater irradiance. Red tide algal blooms, which can cause extreme light reduction in seagrass beds, occur regularly and frequently along the coast of Korea (Kim et al. 2000, Lee et al. 2007a). The detrimental effects of light reduction on seagrass growth during the light attenuation events are predicted to be more severe in deep areas than shallow areas. The disappearance of $Z$. marina shoots at the deep site when light levels decline in September/October is probably caused by light reduction below a threshold level. The re-establishment of this population is completely dependent on sexual reproduction and seedling recruitment. Therefore, we hypothesized that the deep $Z$. marina population responds to low light stress by enhancing sexual reproductive ability, and consequently exhibits an annual life history. To explain the variability in the life history strategy of the shallow and deep $Z$. marina populations, we assessed sexual and asexual reproductive efforts in the 2 populations by constructing life tables using monthly measurements of shoot recruitment and mortality.

\section{MATERIALS AND METHODS}

\section{Study area}

The study site $\left(35^{\circ} 06^{\prime} \mathrm{N}, 128^{\circ} 32^{\prime} \mathrm{E}\right)$ was located in Jindong Bay on the southern coast of Korea. The tidal regime is semi-diurnal with a $1.5 \mathrm{~m}$ tidal range (tide tables for the coast of Korea, Korea Hydrographic and Oceanographic Administration, www.khoa.go.kr). In the relatively shallow area, where water depth 
was $\sim 1$ to $3 \mathrm{~m}$ (mean $=2 \mathrm{~m})$, Zostera marina persisted throughout the year, characteristic of perennial populations. In the relatively deep area, where water depth was $\sim 4$ to $7 \mathrm{~m}$ (mean $=5.5 \mathrm{~m}$ ), only seedlings were observed during winter and spring. In this deep population, surviving seedlings developed to reproductive shoots during spring and summer, and all shoots died off after fall, characteristic of annual populations.

\section{Physical parameters}

PFD at the $Z$. marina canopy level was monitored every $15 \mathrm{~min}$ in the shallow and deep populations using an Odyssey photosynthetic irradiance recording system (Dataflow Systems). The underwater sensor was cleaned every 2 wk to minimize fouling. The logger was calibrated using an LI-1400 data logger and an LI-193SA spherical quantum sensor (Li-Cor). Daily PFD (mol photons $\mathrm{m}^{-2} \mathrm{~d}^{-1}$ ) was calculated as the sum of quantum flux over each $24 \mathrm{~h}$ period. $H_{\text {comp }}$ and $H_{\text {sat }}$ were estimated based on the compensation irradiance of $20 \mu \mathrm{mol}$ photons $\mathrm{m}^{-2} \mathrm{~s}^{-1}$ and the saturation irradiance of $100 \mu \mathrm{mol}$ photons $\mathrm{m}^{-2} \mathrm{~s}^{-1}$ for $Z$. marina (Dennison \& Alberte 1982, Lee et al. 2007b). Water temperature was monitored every $15 \mathrm{~min}$ in the shallow and deep populations using StowAway Tidbit $^{\circledR}$ temperature data loggers (Onset Computer Corporation). Measured water temperatures were averaged daily.

\section{Shoot recruitment and mortality}

To compare life histories of $Z$. marina between the shallow and deep populations, shoot recruitment and mortality through sexual and asexual reproduction were monitored in permanent quadrats. Four replicate quadrats $(0.5 \times 0.5 \mathrm{~m})$ were deployed randomly in each population in December 2007. All Z. marina shoots within the quadrats, including vegetative and reproductive shoots, were marked individually as a means of relative location of each shoot and monitored monthly using a grid quadrat $\left(0.25 \mathrm{~m}^{2}\right)$ divided into 25 sub-quadrats $(0.1 \times 0.1 \mathrm{~m})$. Rates of mortality and recruitment of vegetative and reproductive shoots were estimated as the number of shoots that disappeared and the number of new shoots per unit area $\left(\mathrm{m}^{-2}\right)$, respectively, during each month by comparing marked shoots with the locations of the shoots from the previous month. Because seedlings were too small to mark individually, net recruitment and mortality of seedlings were estimated by comparing seedling densities in the sub-quadrats with values from the previous month. Because $Z$. marina seedlings in this bay system develop to mature plants in summer (Lee et al. 2007a), the survival rate of seedlings was calculated by dividing the number of seedlings surviving until August by the total number of seedlings recruited in each year. The relative contribution of sexual reproduction to the maintenance of the $Z$. marina population was assessed using the relative abundance of seedlings surviving until August in the total shoot density.

\section{Biomass and potential seed production}

All above- and belowground tissues of $Z$. marina inside a quadrat $\left(0.30 \times 0.30 \mathrm{~m}_{i} \mathrm{n}=4\right)$, which was randomly thrown outside the permanent quadrats, were collected monthly for biomass measurements. Belowground tissues were collected to a sediment depth of 15 to $20 \mathrm{~cm}$. Plants were thoroughly cleaned of epiphytes and sediments, separated into aboveground (blade + sheath) and belowground (rhizome + root) tissues, and dried at $60^{\circ} \mathrm{C}$ to a constant weight. Samples were weighed, and biomass was converted to per-unit-area estimates ( $g$ dry weight $\mathrm{m}^{-2}$ ).

To estimate potential seed production, the number of inflorescences per shoot and the number of seeds per inflorescence were counted using 8 to 10 mature reproductive shoots from both the shallow and deep populations between April and June. Potential seed production per shoot was estimated by multiplying the number of inflorescences per shoot by the number of seeds per inflorescence. Seed production per unit area was determined by multiplying the potential seed production per shoot by the reproductive shoot density. To estimate the seed density in the sediment seed bank, 4 to 6 sediment samples were collected to a sediment depth of $\sim 12 \mathrm{~cm}$ monthly from each population using a $9 \mathrm{~cm}$ diameter corer. The core samples were sieved through a $1 \mathrm{~mm}$ mesh screen to remove sediments, and the number of seeds retained on the mesh was counted under a magnifier in the laboratory.

\section{Statistical analysis}

All values are reported as means $\pm \mathrm{SE}$. All statistical analyses were performed using SPSS v.19.0. Data were tested for normality and homogeneity of variance to determine if they met the assumptions of 
parametric statistics. Values of $H_{\text {comp }}, H_{\text {sat, }}$ water temperature, biomass, and shoot density were log-transformed, whereas values of underwater PFD and the number of seeds in the seed bank were square root transformed to satisfy these assumptions. Significant differences in underwater PFD, biomass, the number of inflorescences per shoot, the number of seeds per inflorescence and the number of seeds in sediments among sampling times and between the shallow and deep populations were tested using 2-way ANOVAs. A 2-way ANOVA without replication was used to test for significant differences in daily mean water temperature between the 2 populations. When significant differences $(\alpha=0.05)$ among variables were detected, the means were analyzed using the Student-Newman-Keuls (SNK) test to determine where the significant differences occurred.

\section{RESULTS}

\section{Physical parameters}

Underwater PFD at the Zostera marina canopy level was significantly lower in the deep population than in the shallow population ( $<<0.001$; Fig. 1a). Average daily PFD in the shallow population $(11.2 \mathrm{~mol}$ photons $\mathrm{m}^{-2} \mathrm{~d}^{-1}$ ) was more than twice as high as in the deep population (4.6 mol photons $\mathrm{m}^{-2} \mathrm{~d}^{-1}$ ). Underwater PFD exhibited significant $(p<0.001)$ seasonal variation in both the shallow and deep populations (Fig. 1a). PFD was highest during spring and lowest during fall. Rapid and severe light reductions occurred during late summer and early fall in both populations (Fig. 1a).

$H_{\text {comp }}$ and $H_{\text {sat }}$ were significantly longer in the shallow population than in the deep population $(\mathrm{p}<$ 0.001 ; Fig. $1 \mathrm{~b}, \mathrm{c}) . H_{\text {comp }}$ in the shallow population ranged from 4.8 to $12.5 \mathrm{~h}$, whereas durations in the deep population ranged from 1.8 to $11.0 \mathrm{~h}$ (Fig. 1b). Annual minima of $H_{\text {comp }}$ in the shallow population were $8.1 \mathrm{~h}$ in October 2008 and $4.8 \mathrm{~h}$ in September 2009, whereas the minimum durations in the deep population were $3.8 \mathrm{~h}$ in October 2008 and $1.8 \mathrm{~h}$ in September 2009. $H_{\text {sat }}$ in the shallow population ranged from 1.6 to $9.8 \mathrm{~h}$, whereas the duration in the deep population ranged from 0 to $7.8 \mathrm{~h}$ throughout the experimental periods (Fig. 1c). $H_{\text {sat }}$ decreased to $<3 \mathrm{~h}$ during fall in the deep population.

Water temperatures in both the shallow and deep populations exhibited significant $(\mathrm{p}<0.001)$ seasonal variation, ranging from $29.1^{\circ} \mathrm{C}$ and $28.0^{\circ} \mathrm{C}$ in August 2008 to $4.8^{\circ} \mathrm{C}$ and $4.5^{\circ} \mathrm{C}$ in February 2008 in the
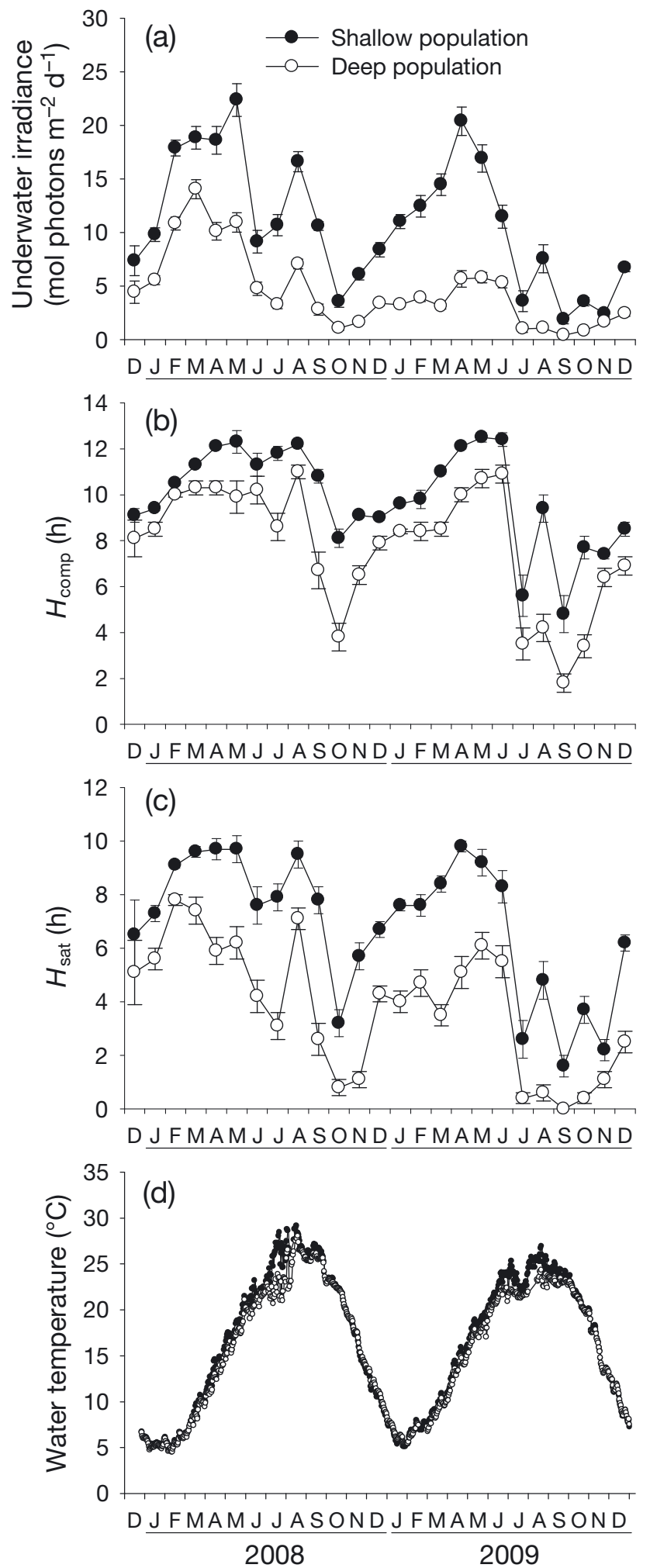

Fig. 1. (a) Daily underwater photon flux density, (b) daily light compensation point $\left(H_{\text {comp }}\right)$, (c) daily light saturation point $\left(H_{\text {sat }}\right)$, and $(\mathrm{d})$ water temperature in the shallow and deep sites with Zostera marina populations in Jindong Bay along the southern coast of Korea from December 2007 to December 2009. Data: mean $\pm \mathrm{SE}$ 
shallow and deep populations, respectively (Fig. 1d). Water temperature was significantly higher in the shallow population than in the deep population $(\mathrm{p}<$ 0.001 ; Fig. 1d). Annual mean water temperatures were $16.8^{\circ} \mathrm{C}$ in 2008 and $16.3^{\circ} \mathrm{C}$ in 2009 for the shallow population, whereas the temperatures were $16.3^{\circ} \mathrm{C}$ in 2008 and $15.7^{\circ} \mathrm{C}$ in 2009 for the deep population.

\section{Above- and belowground biomass}

Total, above-, and belowground biomass were significantly higher in the shallow population than in the deep population $(\mathrm{p}<0.001$; Fig. $2 \mathrm{a}-\mathrm{c})$. Biomass in the shallow population exhibited significant $(\mathrm{p}<$ $0.001)$ seasonal variation, with maximum values in late spring and minimum values in fall. Total and aboveground biomass in the deep population exhibited seasonal trends that were similar to those in the shallow population, but belowground biomass in the deep population increased only slightly during spring, because little rhizome tissue developed in this population. Total, above-, and belowground biomass declined dramatically during high water temperature periods in the summer in both populations. Some vegetative tissues persisted during fall and winter in the shallow population, whereas all plant tissues disappeared after fall in the deep population (Fig. 2a-c). The ratio of above- to belowground biomass was much higher in the deep population than in the shallow population (Fig. 2d).

\section{Shoot recruitment, mortality, and density}

In the shallow area, the $Z$. marina population was maintained through both seedling establishment and asexual clonal growth. Although new shoot recruitment via lateral shoot production was observed throughout the whole year, it predominantly occurred during the winter season (Fig. 3a, Table S1 in the Supplement at www.int-res.com/articles/suppl/ m509p001_supp.pdf). Mortality of vegetative shoots also occurred throughout the whole year (Fig. 3a). The density of vegetative shoots, which did not include seedlings, increased during winter through asexual lateral shoot formation but decreased during summer and fall due to the transformation into reproductive shoots and lower shoot recruitment rates during these periods (Fig. 3a,b). Reproductive shoots in the shallow population began to appear in February and March, and their abundance was highest in May during both 2008 and 2009 (25 and 28 shoots $\mathrm{m}^{-2}$,
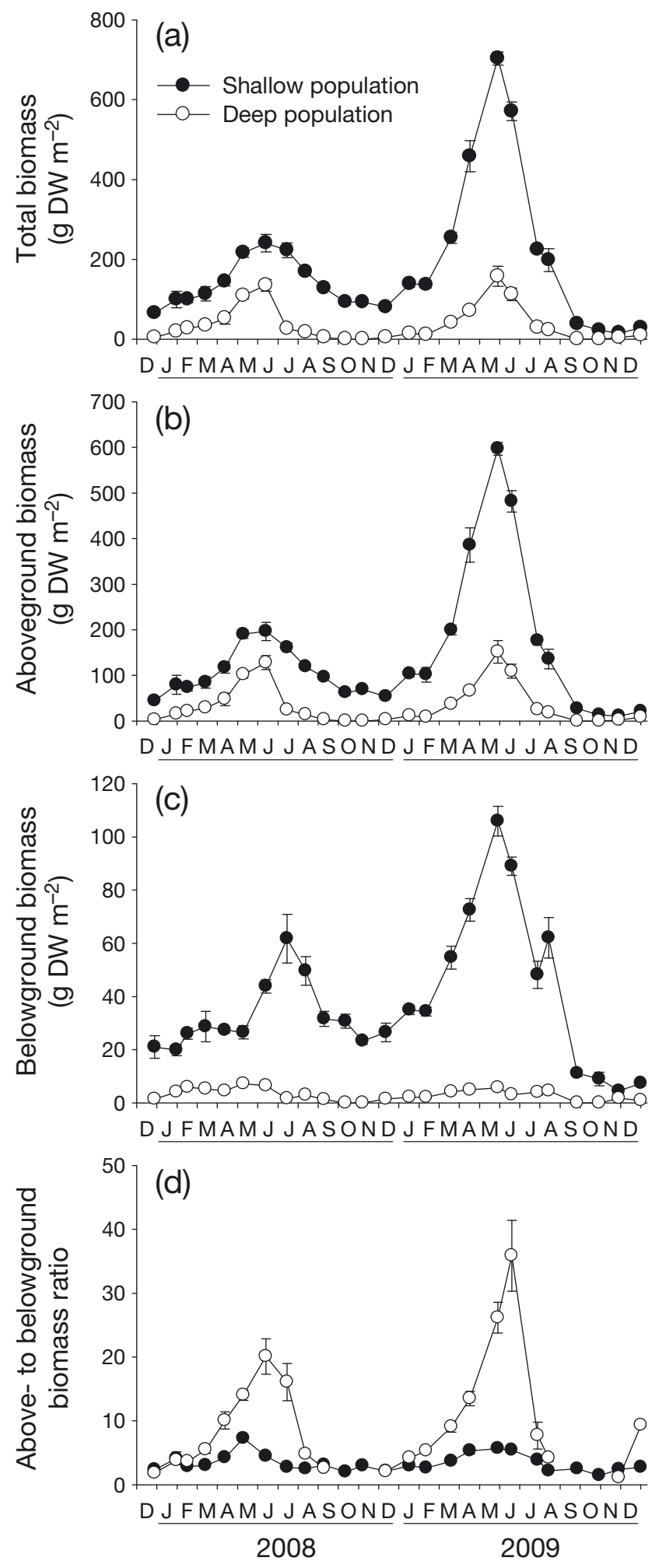

Fig. 2. Zostera marina. Seasonal variation in (a) total, (b) aboveground, and (c) belowground biomass, and (d) the above-/belowground biomass ratio in the shallow and deep populations in Jindong Bay along the southern coast of Korea from December 2007 to December 2009. Data: mean \pm $\mathrm{SE}(\mathrm{n}=4)$ 


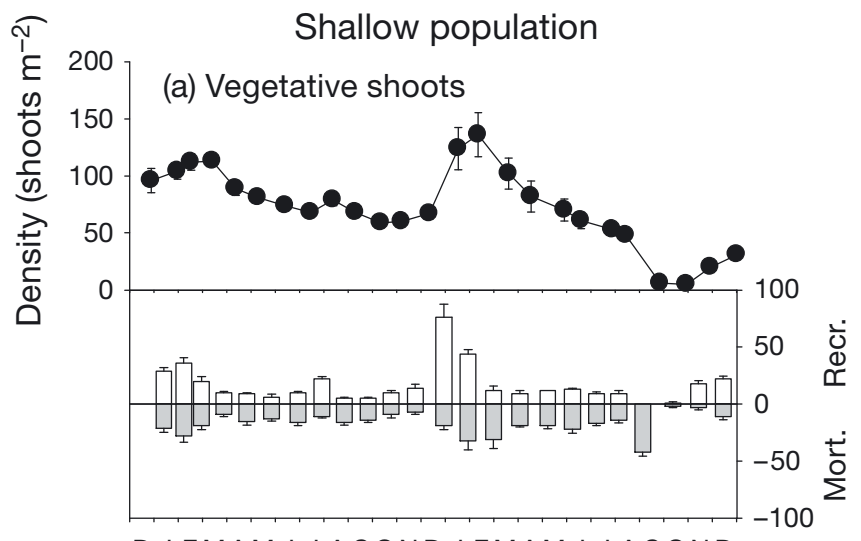

DJFMAMJ JASOND JFMAMJ JASOND

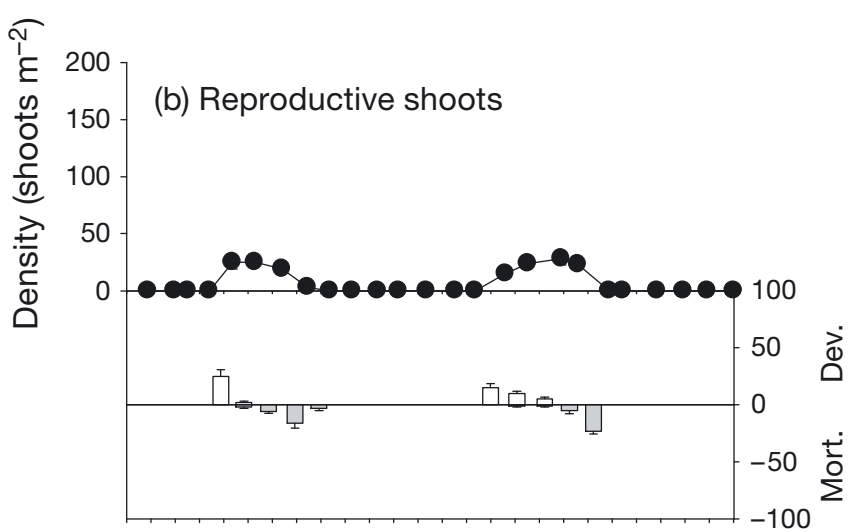

Deep population

D JFMAMJJASOND JFMAMJJASOND

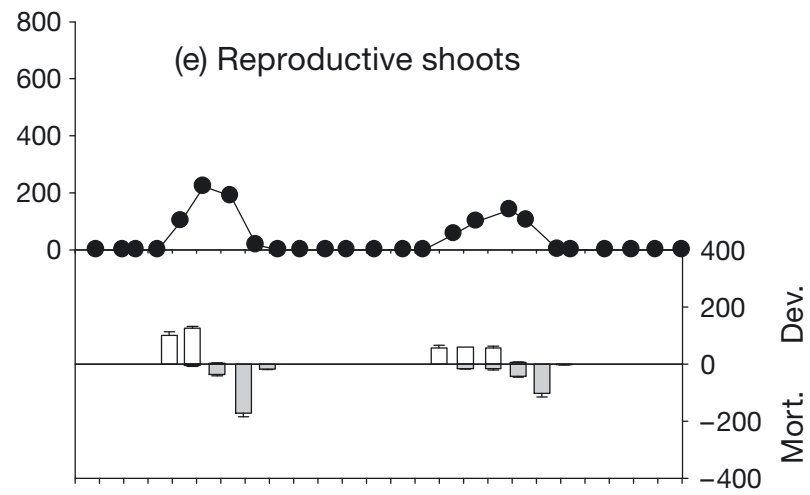

DJFMAMJJASOND JFMAMJJASOND
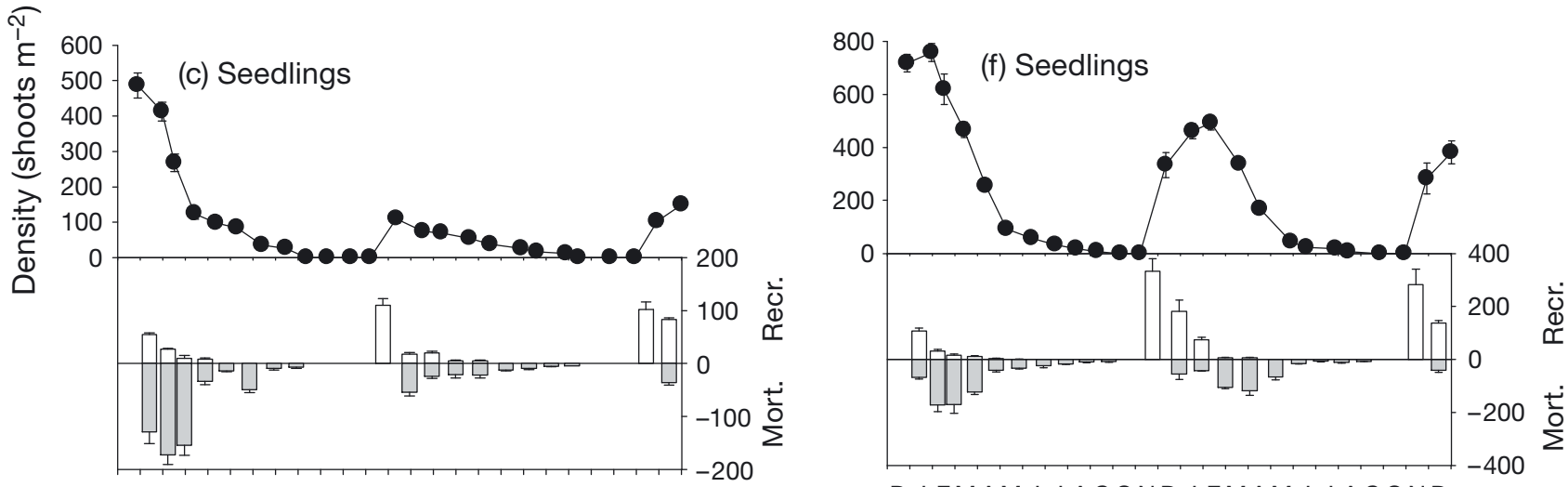

D JFMAMJ JASOND JFMAMJ JASOND
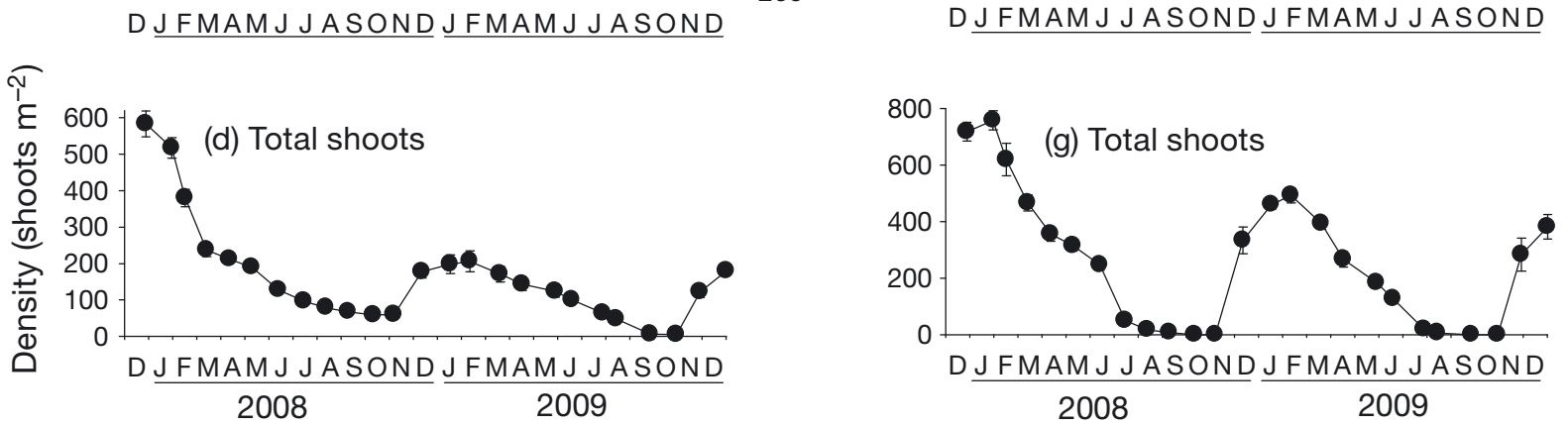

Fig. 3. Zostera marina. Mean density, recruitment, and mortality of different life stages in the (a-d) shallow and (e-g) deep populations in Jindong Bay on the southern coast of Korea from December 2007 to December 2009. (a) Vegetative shoots, (b,e) reproductive shoots, $(\mathrm{c}, \mathrm{f})$ seedlings, and $(\mathrm{d}, \mathrm{g})$ total shoots. Recr.: recruitment; Mort.: mortality; Dev.: development. Error bars: SE 
respectively; Fig. 3b, Table S1). In the shallow population, reproductive shoots developed from adult vegetative shoots but not from seedlings. Although vegetative propagation was observed throughout the whole year, seedling recruitment through seed germination from the seed bank only occurred during late fall to early spring, and the recruitment rate was highest in November in the shallow population (Fig. 3c). Seedling mortality was also high during winter and early spring (Fig. 3c). Only a few seedlings survived until summer (Fig. 3a,c). Per unit area $\left(1 \mathrm{~m}^{2}\right), 587$ (original density in 2007 plus new recruits in 2008) and 158 (new recruits in 2008/2009) seedlings were recruited, but only 19 and 7 seedlings survived to adult vegetative shoots during the years of 2007/2008 and 2008/2009, respectively, in the shallow population (Fig. 3a,c, Table S1). Total shoot density varied significantly $(p<0.001)$ over the sampling months, with the highest values in winter and early spring and the lowest values in fall in the shallow population (Fig. 3d). High shoot density during winter and spring in this population occurred primarily due to high seedling recruitment and lateral shoot formation during these periods (Fig. 3a-d).

In contrast, Z. marina in the deep population was only re-established and maintained by sexual reproduction through seedling recruitment via seed germination (Fig. 3e-g, Table S2 in the Supplement). Seedling recruitment occurred in late fall to early spring, and the recruitment rates were highest in November (Fig. 3f). No lateral shoot production through rhizome branching of seedlings was observed in the deep population throughout the experimental period. More seedlings were recruited in the deep population than in the shallow population (Fig. 3c,f). Seedlings in the deep population decreased dramatically during spring due to high mortality and transformation to reproductive shoots (Fig. 3e,f). Reproductive shoots began to appear in early spring, and all reproductive shoots developed from seedlings in the year of germination (Fig. 3e). On a per $\mathrm{m}^{2}$ basis, 891 and 603 seedlings were re- cruited, and 644 and 417 seedlings died off before developing into adult shoots or reproductive shoots during the years of 2007/2008 and 2008/2009, respectively, in the deep population (Fig. 3e,f, Table S2). Approximately 230 and 179 seedlings developed to reproductive shoots during spring in 2008 and 2009, respectively (Fig. 3e). After detachment of senescent reproductive shoots, only a few seedlings (17 and 7 seedlings in 2008 and 2009, respectively) grew to adult vegetative shoots, but all shoots died off during fall, resulting in the absence of overwintering shoots in the deep population (Fig. 3e-g). Total shoot density was highest in winter due to high seedling recruitment during this period, but densities decreased dramatically during spring due to high seedling mortality (Fig. 3f,g).

\section{Potential seed production and seed density}

Although the number of inflorescences per shoot and the number of seeds per inflorescence were significantly higher in the shallow population than in the deep population (both $\mathrm{p}<0.001$ ), potential seed production was higher in the deep population ( 8000 to 10000 seeds $\mathrm{m}^{-2}$ ) than in the shallow population ( 6000 to 7000 seeds $\mathrm{m}^{-2}$ ) due to the much higher reproductive shoot density at the deep site (Table 1). Seed density in the sediment seed bank did not differ significantly between the 2 populations $(p=0.121$; Fig. 4). Seed density in the sediment seed bank exhibited significant seasonal variation in both the shallow and deep populations ( $p<0.001$; Fig. 4). Seed density in the sediment seed bank was highest in summer following the release of seeds from reproductive shoots and lowest in spring following the germination of seeds. Maximum seed densities were 1834 and $3274 \mathrm{~m}^{-2}$ in the shallow population and 2138 and $3120 \mathrm{~m}^{-2}$ in the deep population in 2008 and 2009, respectively (Fig. 4). A few seeds ( 0 to 40 seeds $\mathrm{m}^{-2}$ ) remained in the sediment seed bank after the germination season in both populations (Fig. 4).

Table 1. Zostera marina. Potential seed production (mean \pm SE) calculated from reproductive shoot density, the number of inflorescences per shoot, and the number of seeds per inflorescence in the shallow and deep populations in Jindong Bay along the southern coast of Korea in 2008 and 2009

\begin{tabular}{|llcccc|}
\hline Year & Site & $\begin{array}{c}\text { Reproductive shoot density } \\
\left(\text { no. of shoots } \mathrm{m}^{-2} \text { ) }\right.\end{array}$ & $\begin{array}{c}\text { No. inflorescences } \\
\text { per shoot }\end{array}$ & $\begin{array}{c}\text { No. seeds per } \\
\text { inflorescence }\end{array}$ & $\begin{array}{c}\text { Potential seed production } \\
\left(\text { no. of seeds } \mathrm{m}^{-2} \text { ) }\right.\end{array}$ \\
\hline 2008 & Shallow & $27.0 \pm 4.7$ & $23.0 \pm 1.2$ & $9.7 \pm 0.2$ & 6024 \\
& Deep & $230.0 \pm 13.6$ & $5.5 \pm 0.2$ & $6.5 \pm 0.3$ & 8223 \\
2009 & Shallow & $30.0 \pm 6.2$ & $22.8 \pm 1.2$ & $10.4 \pm 0.2$ & 7114 \\
& Deep & $179.0 \pm 17.0$ & $8.2 \pm 0.7$ & $6.8 \pm 0.3$ & 9981 \\
\hline
\end{tabular}




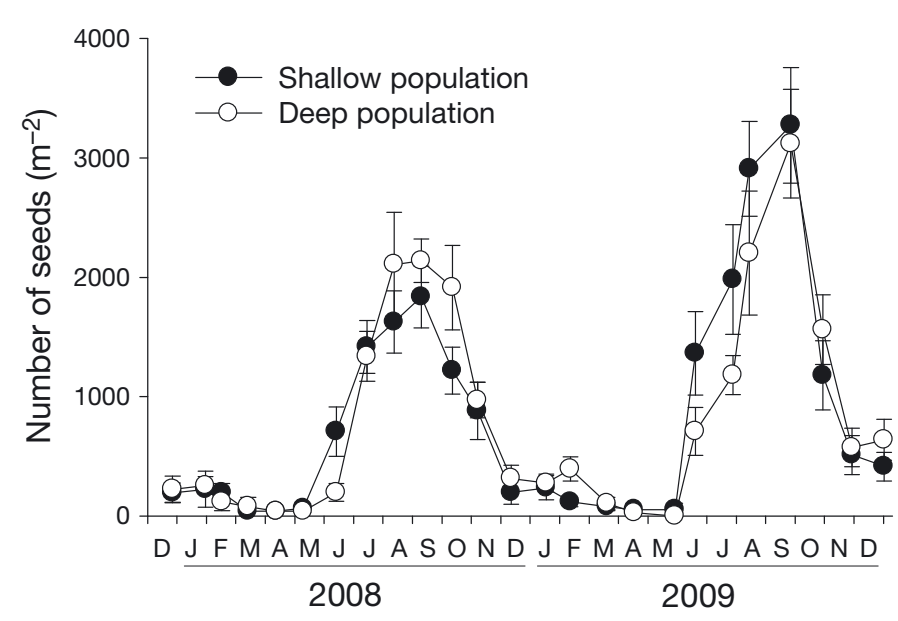

Fig. 4. Zostera marina. Seasonal variation in seed density (mean $\pm 1 \mathrm{SE} ; \mathrm{n}=4$ to 6 ) within the sediment seed bank in the shallow and deep populations in Jindong Bay on the southern coast of Korea from December 2007 to December 2009

\section{Life history}

The shallow population displayed a perennial life history strategy, whereas the deep population exhibited an annual life history strategy (Fig. 5). In the shallow population, overwintered vegetative shoots as well as seedlings that germinated in winter and spring co-existed at the beginning of the growing season (Fig. 5a). Among the newly recruited seedlings in the shallow population, only 3.2 and $4.4 \%$ of seedlings survived to adult shoots in 2008 and 2009, respectively. Approximately 30 to $45 \%$ of the overwintered vegetative shoots developed into reproductive shoots, and none of the seedlings flowered in this population. In fall, after the detachment of senescent reproductive shoots, 15 to $25 \%$ of the vegetative shoots were those derived from seedlings (Fig. 5a). Approximately 30 and $46 \%$ of the seeds produced in 2008 and 2009, respectively, were found in the sediment seed bank when seed density in sediments showed a maximum, and $8.6 \%$ of seeds in sediments germinated and developed to seedlings in the shallow population (Fig. 5a). Although shoot density decreased during summer and fall, $\sim 30$ to 70 shoots $\mathrm{m}^{-2}$ overwintered in the shallow population.

In contrast to the shallow population, no overwintering shoots were observed in the deep population, and only seedling recruitment contributed to the maintenance of this population (Fig. 5b). Approximately $70 \%$ of the newly recruited seedlings died before developing into reproductive shoots or adult vegetative shoots (Fig. 5b). Approximately 93 and $96 \%$ of the surviving seedlings (25.8 and $29.7 \%$ of the total recruited seedlings) developed into reproductive shoots in 2008 and 2009, respectively (Fig. 5b). Only $1-2 \%$ of seedlings survived until summer and grew to adult vegetative shoots, which did not develop to reproductive shoots (Fig. 5b). However, none of the shoots overwintered in the deep population (Fig. 5b). Approximately 25 to $30 \%$ (26.0 and $31.3 \%$ in 2008 and 2009, respectively) of the produced seeds were found in the sediment seed bank when the seed density peaked in summer, and $28.2 \%$ of the seeds in the sediment seed bank germinated and developed to seedlings in the deep population (Fig. 5b).

\section{DISCUSSION}

\section{Comparison of reproductive strategies between two populations}

Zostera marina populations in our study site exhibited 2 different life history strategies at the different water depths. In the deep area, Z. marina maintained its population only through sexual reproduction, in which shoot recruitment was solely achieved through the germination of seeds. The flowering frequency $(\sim 95 \%)$ observed in the present deep population was similar to values observed in typical annual populations (Keddy \& Patriquin 1978, Meling-López \& Ibarra-Obando 1999, Santamaría-Gallegos et al. 2000). None of the $Z$. marina shoots in the deep population survived after fall. In contrast, the $Z$. marina population in the shallow area persisted through both asexual and sexual reproduction and exhibited a typical perennial life cycle. The flowering frequency $(\sim 35 \%)$ in the shallow population was similar to values reported in other perennial $Z$. marina beds along the coasts of Korea (Lee et al. 2005, Kim et al. 2008). Perennial Z. marina generally requires at least $2 \mathrm{yr}$ of vegetative growth for reproductive shoot development (Tutin 1942, Olesen 1999). Similarly, no lateral shoots or seedlings flowered during the first year of asexual lateral shoot formation or seedling germination in our shallow population.

$Z$. marina populations that display a mixture of annual and perennial life history strategies are considered to have a 'semi-annual' or 'mixed-annual' life history strategy (van Lent \& Verschuure 1994, Jarvis et al. 2012). In the mixed-annual population, only some of the newly established seedlings develop into reproductive shoots. The observed flowering frequency in our deep population was much higher than values observed in mixed-annual or semi-annual 
(a) Shallow population

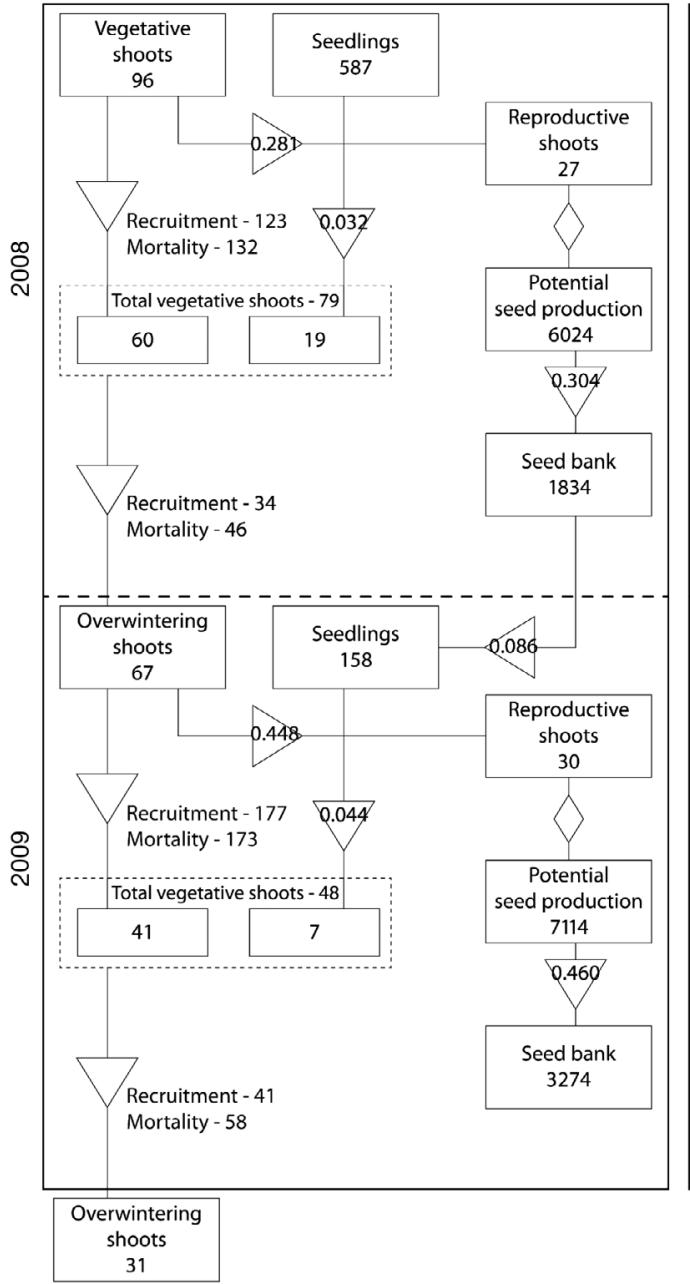

(b) Deep population

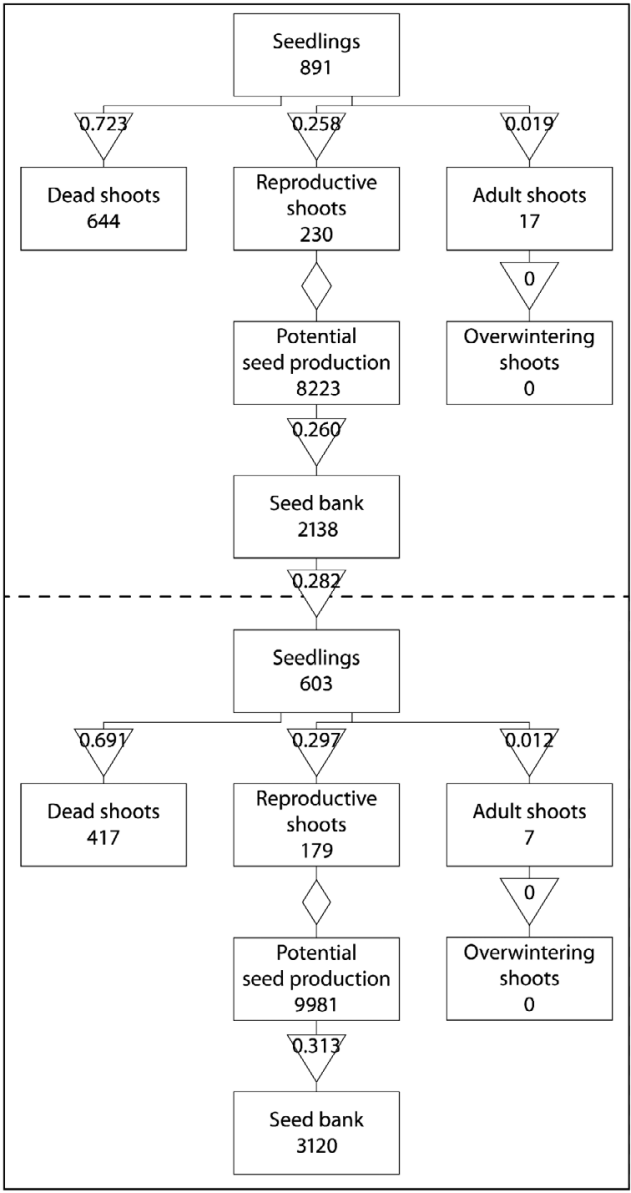

Fig. 5. Diagrammatic life tables of Zostera marina in the (a) shallow and (b) deep populations at the study site on the southern coast of Korea. Rectangles: stages of the life cycle (values are number per unit area, $\mathrm{m}^{-2}$ ), triangles: transition probabilities between stages, and diamonds: seed production

populations that exhibit reproductive efforts of $\sim 45 \%$ in the southwestern Netherlands (van Lent \& Verschuure 1994) and a flowering proportion of $33 \%$ in the western North Atlantic (Jarvis et al. 2012). After the loss of senescent reproductive shoots, the remaining vegetative shoots experience $100 \%$ mortality in the fall; consequently, no overwintering shoots are observed in the mixed-annual populations (Jarvis et al. 2012). Because newly established seedlings in the mixed-annual populations establish more rapidly than in the annual populations by reproducing both sexually and asexually, this life history strategy may facilitate population persistence during times of stressful environmental conditions (Jarvis et al. 2012). Unlike mixed-annual populations, none of the newly established seedlings in our deep population reproduced asexually through clonal growth.
Z. marina plants in the deep population at our study site exhibited morphological features of annual plants. Annual Z. marina plants have been distinguished from perennial plants by the very short rhizome and the lack of asexual lateral shoot production from rhizome branching (Keddy \& Patriquin 1978, Robertson \& Mann 1984, van Lent \& Verschuure 1994, Meling-López \& Ibarra-Obando 1999, SantamaríaGallegos et al. 2000). The above- to belowground biomass ratio in the deep population was much higher than the values observed in our shallow population or in other perennial $Z$. marina populations (Lee et al. 2005, Park et al. 2009). Vegetative expansion in perennial populations requires more non-structural carbohydrate reserves and nutrient allocation to rhizomes (Burke et al. 1996, Duarte \& Sand-Jensen 1996). However, annual plants generally invest little 
into belowground biomass and instead allocate more production to structures associated with seed production (Robertson \& Mann 1984, Madsen 1991, van Lent \& Verschuure 1994). In the present study, the deep population allocated 80 to $90 \%$ of total production towards structures for seed production, whereas the shallow population allocated only 25 to $50 \%$ of production to reproductive structures.

Seed banks in sediments and seedling recruitment from the seed bank play critical roles in the maintenance of wetland plant populations (Peterson \& Baldwin 2004). Z. marina, which is a prolific seedproducing plant, varies spatially and temporally in terms of seed production and seed density in the sediment seed bank (Harwell \& Orth 2002, Reusch 2003, Lee et al. 2007a). The yearly seed production of $Z$. marina is typically significantly higher in annual populations compared to perennial populations; much higher flowering frequencies have been observed in the annual population (Olesen 1999, Jarvis et al. 2012). In the present study, potential seed production was higher in the deep population than in the shallow population. Reproductive shoot density was $\sim 6$ to 9 times higher in the deep population than in the shallow population. Because annual-type plants in the deep population were much smaller in size with fewer branches bearing spadices compared with the perennial shoots in the shallow population, the number of inflorescences per shoot and the number of seeds per inflorescence were significantly higher in the shallow population. Thus, the higher potential seed production in the deep population was the result of the higher reproductive shoot density compared with the shallow population.

Although potential seed production was higher in the deep population than in the shallow population, seed densities in the sediment seed banks did not differ significantly between the 2 populations in this study. A larger proportion of the produced seeds is retained in the sediment seed bank in perennial populations $(0.8$ to $36.8 \%)$ than in annual populations ( 0.5 to $1.9 \%$ ) of Z. marina (van Lent \& Verschuure 1994). Our findings support this research: a smaller proportion of the produced seeds remained in the bottom sediment in the annual deep population compared with the perennial shallow population. Large numbers of $Z$. marina seeds probably disperse to areas outside the population or may be consumed (Fishman \& Orth 1996, Nakaoka 2002). Upright shoots in the shallow population may have acted as a seed trap during fall, whereas all shoots disappeared in the deep population after fall; thus, relatively more seeds in the deep population were likely swept away from the eelgrass bed in winter. While there is a possibility of seed transport between the shallow and deep populations, most germinated seedlings in the deep population exhibited characteristics of an annual life history. Thus, the seed transport between the populations may be negligible. Further experiments in the seed germination and the export of flowering shoots are needed to clarify the extent of seed transport between the populations.

Only a small portion of $Z$. marina seeds in sediments successfully germinates into seedlings (Olesen 1999, Lee et al. 2007a, Jarvis et al. 2012). Lower germination rates of seeds in sediment seed banks have been reported in perennial $Z$. marina beds than in annual beds (van Lent \& Verschuure 1994). Our findings support these results: $\sim 8.6 \%$ of the seeds in sediments germinated in the perennial-type shallow population, whereas $28.2 \%$ of seeds germinated in the annual-type deep population. In eelgrass beds in the western North Atlantic, no viable seeds in the seed bank were found after the germination season (Jarvis et al. 2012). Therefore, although we observed a few seeds in the sediment after the germination season in both the deep and shallow populations, these may not have been viable.

Following seed germination, the establishment of seedlings is affected by various factors such as pathogens, predation, inter- and intraspecific competition, and shading by adult shoots (Robertson \& Mann 1984, Chambers \& MacMahon 1994, Clark et al. 2007). Seedlings of $Z$. marina are vulnerable to abiotic and biotic environmental stresses, often resulting in low survival rates (Hauxwell et al. 2001, Greve et al. 2005). Lower growth and survival rates among seedlings have been observed in established $Z$. marina beds compared to areas without standing shoots, implying that mortality and suppressed growth are caused by density-dependent competition (Robertson \& Mann 1984, Olesen 1999). Compared with the deep population at our study site, seedling survival rates were significantly lower in the shallow population, in which matured Z. marina shoots were present when seedlings developed. Approximately $30 \%$ of seedlings that recruited during late fall to early spring developed into reproductive shoots or adult vegetative shoots in the deep population, whereas $<5 \%$ of seedlings in the shallow population developed into adult vegetative shoots, which accounted for 15 to $25 \%$ of total shoots at the time. These results suggest that sexual reproduction contributed $\sim 15$ to $25 \%$ of total shoot production for the persistence of the population in the shallow area, whereas the deep population was maintained completely by sexual reproduction. 


\section{Reproductive adaptation for population persistence}

Seagrasses tend to allocate more energy to sexual reproduction under conditions of environmental stress (Alexandre et al. 2005, Cabaço \& Santos 2012). Thus, an annual life history strategy is considered an adaptation to stressful conditions (Robertson \& Mann 1984). The annual life form of $Z$. marina has been observed in areas subjected to environmental stresses such as ice formation, severe storms, and extreme water temperatures (Keddy \& Patriquin 1978, Robertson \& Mann 1984, van Lent \& Verschuure 1994, Meling-López \& Ibarra-Obando 1999, SantamaríaGallegos et al. 2000). For example, high summer water temperatures can induce the complete loss of biomass in annual-type $Z$. marina populations at the southern limit of the species distribution in the Gulf of California and the western North Atlantic (Santamaría-Gallegos et al. 2000, Jarvis et al. 2012). In the present study, water temperatures at both the shallow and the deep site reached $\sim 28$ to $29^{\circ} \mathrm{C}$ in August, which is much higher than the optimal growth temperature $\left(15\right.$ to $\left.20^{\circ} \mathrm{C}\right)$ for $Z$. marina in this area (Lee et al. 2005). Thus, shoot densities at both sites significantly decreased in summer and early fall. However, because both populations experienced high water temperature stress, the difference in life history strategy between the 2 populations must have another reason.

Severe reductions in underwater irradiance at the deep population during fall, following the detrimental effect of high summer water temperature, corresponded with the complete loss of $Z$. marina shoots in this population. The survival of seagrass is closely related to underwater PFD and duration of $H_{\text {comp }}$ (Dennison 1987, Lee et al. 2007b). Non-lightlimited growth of $Z$. marina in the Pacific Northwest reportedly requires at least $7 \mathrm{~mol}$ photons $\mathrm{m}^{-2} \mathrm{~d}^{-1}$, whereas long-term survival requires a minimum average of $3 \mathrm{~mol}$ photons $\mathrm{m}^{-2} \mathrm{~d}^{-1}$ (Thom et al. 2008). Seedlings of $Z$. marina require a minimum of $8 \mathrm{~mol}$ photons $\mathrm{m}^{-2} \mathrm{~d}^{-1}$ on average for rhizome and leaf growth during their first summer (Bintz \& Nixon 2001). When mean daily PFD drops to 3.3 mol photons $\mathrm{m}^{-2} \mathrm{~d}^{-1}$ during summer, $Z$. marina seedlings do not survive in winter due to inadequate rhizome reserves (Bintz \& Nixon 2001). In the present study, underwater PFD in the shallow population was above 7 mol photons $\mathrm{m}^{-2} \mathrm{~d}^{-1}$ except during fall. The average daily underwater PFD was much lower in the deep population (4.6 mol photons $\mathrm{m}^{-2} \mathrm{~d}^{-1}$ ) than in the shallow population (11.2 mol photons $\left.\mathrm{m}^{-2} \mathrm{~d}^{-1}\right)$. In particular, PFD was $<3$ mol photons $\mathrm{m}^{-2} \mathrm{~d}^{-1}$ during fall in the deep population. Thus, $Z$. marina shoots in the deep population were probably exposed to irradiance levels lower than the minimum light requirement for survival during fall; consequently, 100\% shoot mortality was observed in this population.

The lengths of $H_{\text {comp }}$ and $H_{\text {sat }}$ have been closely related with growth and survival in $Z$. marina (Dennison \& Alberte 1982, 1985, Dennison 1987). The minimum $H_{\text {comp }}$ for survival was $12.3 \mathrm{~h}$ in $Z$. marina beds in Great Harbor, MA (Dennison 1987). Z. marina growth significantly decreases when $H_{\text {sat }}$ values falls below $10 \mathrm{~h}$, and $H_{\text {sat }}$ values of at least $6 \mathrm{~h}$ have been suggested as the minimum light requirement for $Z$. marina growth and survival (Dennison \& Alberte 1985). In the present study, $H_{\text {comp }}$ and $H_{\text {sat }}$ during fall in the deep population were much shorter than the minimum values for survival and growth of $Z$. marina (Dennison \& Alberte 1985, Dennison 1987, Lee et al. 2007b). $H_{\text {comp }}$ decreased to $2-4 \mathrm{~h}$, and $H_{\text {sat }}$ decreased to nearly $0 \mathrm{~h}$. $\mathrm{Z}$. marina plants in the deep population appeared to receive insufficient light for overwintering. Because no vegetative shoots survived after fall in the deep population, this population could only be maintained through seedling recruitment by sexual reproduction. Terrestrial angiosperms such as Mimulus guttatus and Oryza nivara exhibit adaptive life history strategies in response to unfavorable environmental conditions by increasing sexual reproduction (van Kleunen 2007, Grillo et al. 2009). Thus, the deep population of $Z$. marina may display an annual life history strategy by enhancing the ability of sexual reproduction to achieve persistence of the population under unfavorable light conditions.

In conclusion, repetitive and acute light reductions occurred in the deep $Z$. marina population at our study site following high water temperature stress in summer. The light reduction during summer and fall was likely lethal to $Z$. marina shoots that also experienced the detrimental effects of high summer water temperature. Thus, these consecutive stressors likely led to the mortality of $Z$. marina shoots after fall in the deep population. Since the deep $Z$. marina population could only be re-established and maintained by sexual reproduction, $Z$. marina in this population probably enhanced the ability of sexual reproduction through an increase of flowering frequency. An annual-type life history of plants is considered to have evolved from a perennial life history as an adaptation to stressful environmental conditions for population persistence (van Kleunen 2007, Grillo et al. 2009). Thus, the deep $Z$. marina population in this study exhibits an annual life history strategy to achieve population persistence under repetitive and acute unfavorable environmental conditions. 
Acknowledgements. We thank Y. K. Kim, J. W. Kim, S. H. Park, and J. I. Park for their countless hours of field and laboratory assistance. Anonymous reviewers provided extremely helpful comments on an earlier version of the manuscript. This work was supported by the Ministry of Oceans and Fisheries, Korea (project title: Long-term change of structure and function in marine ecosystems of Korea) and the National Research Foundation of Korea (NRF) grant funded by the Korean government (MEST; NRF-2012 R1A1A2004493).

\section{LITERATURE CITED}

- Alcoverro T, Zimmerman RC, Kohrs DG, Alberte RS (1999) Resource allocation and sucrose mobilization in lightlimited eelgrass Zostera marina. Mar Ecol Prog Ser 187: 121-131

Alexandre A, Santos R, Serrão E (2005) Effects of clam harvesting on sexual reproduction of the seagrass Zostera noltii. Mar Ecol Prog Ser 298:115-122

Biber PD, Kenworthy WJ, Paerl HW (2009) Experimental analysis of the response and recovery of Zostera marina (L.) and Halodule wrightii (Ascher.) to repeated lightlimitation stress. J Exp Mar Biol Ecol 369:110-117

Bintz JC, Nixon SW (2001) Responses of eelgrass Zostera marina seedlings to reduced light. Mar Ecol Prog Ser 223:133-141

Burke MK, Dennison WC, Moore KA (1996) Non-structural carbohydrate reserves of eelgrass Zostera marina. Mar Ecol Prog Ser 137:195-201

Cabaço S, Santos R (2012) Seagrass reproductive effort as an ecological indicator of disturbance. Ecol Indic 23: 116-122

Cabello-Pasini A, Lara-Turrent C, Zimmerman RC (2002) Effect of storms on photosynthesis, carbohydrate content and survival of eelgrass populations from a coastal lagoon and the adjacent open ocean. Aquat Bot 74: 149-164

> Cabello-Pasini A, Muñiz-Salazar R, Ward DH (2003) Annual variations of biomass and photosynthesis in Zostera marina at its southern end of distribution in the North Pacific. Aquat Bot 76:31-47

Chambers JC, MacMahon JC (1994) A day in the life of a seed: movements and fates of seeds and their implications for natural and managed systems. Annu Rev Ecol Evol Syst 25:263-292

> Clark CJ, Poulsen JR, Levey DJ, Osenberg CW (2007) Are plant populations seed limited? A critique and meta analysis of seed addition experiments. Am Nat 170: 128-142

> Dennison WC (1987) Effects of light on seagrass photosynthesis, growth and depth distribution. Aquat Bot 27: 15-26

> Dennison WC, Alberte RS (1982) Photosynthetic responses of Zostera marina L. (eelgrass) to in situ manipulations of light intensity. Oecologia 55:137-144

Dennison WC, Alberte RS (1985) Role of daily light period in the depth distribution of Zostera marina (eelgrass). Mar Ecol Prog Ser 25:51-61

> Duarte CM, Sand-Jensen K (1996) Nutrient constraints on establishment from seed and on vegetative expansion of the Mediterranean seagrass Cymodocea nodosa. Aquat Bot 54:279-286

Fishman JR, Orth RJ (1996) Effects of predation on Zostera marina L. seed abundance. J Exp Mar Biol Ecol 198: 11-26

- Greve TM, Krause-Jensen D, Rasmussen MB, Christensen PB (2005) Means of rapid eelgrass (Zostera marina L.) recolonisation in former dieback areas. Aquat Bot 82: 143-156

Grillo MA, Li C, Fowlkes AM, Briggeman TM, Zhou A, Schemske DW, Sang T (2009) Genetic architecture for the adaptive origin of annual wild rice, Oryza nivara. Evolution 63:870-883

Harwell MC, Orth RJ (2002) Seed bank patterns in Chesapeake Bay eelgrass (Zostera marina L.): a bay-wide perspective. Estuaries 25:1196-1204

> Hauxwell J, Cebrián J, Furlong C, Valiela I (2001) Macroalgal canopies contribute to eelgrass (Zostera marina) decline in temperate estuarine ecosystems. Ecology 82: 1007-1022

> Holmer M, Laursen L (2002) Effect of shading of Zostera marina (eelgrass) on sulfur cycling in sediments with contrasting organic matter and sulfide pools. J Exp Mar Biol Ecol 270:25-37

> Jarvis JC, Moore KA, Kenworthy WJ (2012) Characterization and ecological implication of eelgrass life history strategies near the species' southern limit in the western North Atlantic. Mar Ecol Prog Ser 444:43-56

Keddy CJ, Patriquin DG (1978) An annual form of eelgrass in Nova Scotia. Aquat Bot 5:163-170

Kim HG, Lee PY, Lee SG, Choi YC, Cho HG (2000) Handbook on oceanography, marine environment and harmful algal blooms. National Fisheries Research \& Development Institute, Busan

Kim TH, Park SR, Kim YK, Kim JH and others (2008) Growth dynamics and carbon incorporation of the seagrass, Zostera marina L. in Jindong Bay and Gamak Bay on the southern coast of Korea. Algae 23:241-250

Lee KS, Lee SY (2003) The seagrasses of the Republic of Korea. In: Green EP, Short FT (eds) World atlas of seagrasses. University of California Press, Berkeley, CA, p 193-198

> Lee KS, Park SR, Kim JB (2005) Production dynamics of the eelgrass, Zostera marina in two bay systems on the south coast of the Korean peninsula. Mar Biol 147: 1091-1108

Lee KS, Park JI, Kim YK, Park SR, Kim JH (2007a) Recolonization of Zostera marina following destruction caused by a red tide algal bloom: the role of new shoot recruitment from seed banks. Mar Ecol Prog Ser 342:105-115

> Lee KS, Park SR, Kim YK (2007b) Effects of irradiance, temperature, and nutrients on growth dynamics of seagrasses: a review. J Exp Mar Biol Ecol 350:144-175

> Madsen JD (1991) Resource allocation at the individual plant level. Aquat Bot 41:67-86

> Meling-López AE, Ibarra-Obando SE (1999) Annual life cycles of two Zostera marina L. populations in the Gulf of California: contrasts in seasonality and reproductive effort. Aquat Bot 65:59-69

Moore KA, Short FT (2006) Zostera: biology, ecology, and management. In: Larkum AWD, Orth RJ, Duarte CM (eds) Seagrasses: biology, ecology and conservation. Springer, Dordrecht, p 361-386

Muñiz-Salazar R, Talbot SL, Sage GK, Ward DH, CabelloPasini A (2005) Population genetic structure of annual and perennial populations of Zostera marina L. along the Pacific coast of Baja California and the Gulf of California. Mol Ecol 14:711-722 
Nakaoka M (2002) Predation on seeds of seagrasses Zostera marina and Zostera caulescens by a tanaid crustacean Zeuxo sp. Aquat Bot 72:99-106

Nielsen SL, Sand-Jensen K, Borum J, Geertz-Hansen O (2002) Depth colonization of eelgrass (Zostera marina) and macroalgae as determined by water transparency in Danish coastal waters. Estuaries 25:1025-1032

Olesen B (1999) Reproduction in Danish eelgrass (Zostera marina L.) stands: size-dependence and biomass partitioning. Aquat Bot 65:209-219

Olesen B, Sand-Jensen K (1994) Demography of shallow eelgrass (Zostera marina) populations - shoot dynamics and biomass development. J Ecol 82:379-390

Park SR, Kim JH, Kang CK, An S, Chung IK, Kim JH, Lee KS (2009) Current status and ecological roles of Zostera marina after recovery from large-scale reclamation in the Nakdong River estuary, Korea. Estuar Coast Shelf Sci 81: 38-48

Peterson JE, Baldwin AH (2004) Seedling emergence from seed banks of tidal freshwater wetlands: response to inundation and sedimentation. Aquat Bot 78:243-254

Plus M, Deslous-Paoli JM, Dagault F (2003) Seagrass (Zostera marina L.) bed recolonisation after anoxiainduced full mortality. Aquat Bot 77:121-134

Reusch TBH (2003) Floral neighbourhoods in the sea: how floral density, opportunity for outcrossing and population fragmentation affect seed set in Zostera marina. J Ecol 91:610-615

Editorial responsibility: Just Cebrian,

Dauphin Island, Alabama, USA
Robertson A, Mann K (1984) Disturbance by ice and lifehistory adaptations of the seagrass Zostera marina. Mar Biol 80:131-141

Santamaría-Gallegos NA, Sánchez-Lizaso JL, Félix-Pico EF (2000) Phenology and growth cycle of annual subtidal eelgrass in a subtropical locality. Aquat Bot 66:329-339

> Thom R, Southard S, Borde A, Stoltz P (2008) Light requirements for growth and survival of eelgrass (Zostera marina L.) in Pacific Northwest (USA) Estuaries. Estuaries Coasts 31:969-980

Tutin TG (1942) Zostera L. J Ecol 30:217-226

van Kleunen M (2007) Adaptive genetic differentiation in life-history traits between populations of Mimulus guttatus with annual and perennial life-cycles. Evol Ecol 21: 185-199

van Lent F, Verschuure JM (1994) Intraspecific variability of Zostera marina L. (eelgrass) in the estuaries and lagoons of the southwestern Netherlands. I. Population dynamics. Aquat Bot 48:31-58

Zimmerman RC, Cabello-Pasini A, Alberte RS (1994) Modeling daily production of aquatic macrophytes from irradiance measurements: a comparative analysis. Mar Ecol Prog Ser 114:185-196

Zimmerman RC, Steller DL, Kohrs DG, Alberte RS (2001) Top-down impact through a bottom-up mechanism. In situ effects of limpet grazing on growth, light requirements and survival of the eelgrass Zostera marina. Mar Ecol Prog Ser 218:127-140

Submitted: September 25, 2013; Accepted: May 30, 2014 Proofs received from author(s): July 11, 2014 